The Holocene

\title{
Palaeoenvironmental history of the last six centuries in the Nettilling Lake area (Baffin Island, Canada): A multi-proxy analysis
}

\begin{tabular}{|c|c|}
\hline Journal: & The Holocene \\
\hline Manuscript ID & HOL-14-0258.R2 \\
\hline Manuscript Type: & Paper \\
\hline Date Submitted by the Author: & 13-Feb-2016 \\
\hline Complete List of Authors: & $\begin{array}{l}\text { Beaudoin, Anne; Université Laval, Département de géographie } \\
\text { Pienitz, Reinhard; Université Laval, Département de géographie } \\
\text { FRANCUS, Pierre; INRS, ETE } \\
\text { Zdanowicz, Christian; Uppsala Universitet, Earth Sciences } \\
\text { St Onge, Guillaume; UQAR, ISMER }\end{array}$ \\
\hline Keywords: & $\begin{array}{l}\text { Nettilling Lake, Penny Ice Cap, Baffin Island, Lake sediment, Palaeoclimate, } \\
\text { Little Ice Age }\end{array}$ \\
\hline Abstract: & $\begin{array}{l}\text { The Baffin Island region in the eastern Canadian Arctic has recently } \\
\text { experienced a rapid warming, possibly unprecedented in millennia. To } \\
\text { investigate the response of freshwater environments to this warming and } \\
\text { place it in a secular perspective, we analyzed a } 80-\mathrm{cm} \text { long sediment core } \\
\text { from Nettilling Lake, the largest lake of the Canadian Arctic Archipelago. } \\
\text { The core was taken from a part of the lake basin that receives meltwater } \\
\text { and sediment inputs from the nearby Penny Ice Cap. The core time scale, } \\
\text { established using } 137 \mathrm{Cs} \text { and palaeomagnetic techniques, spans an } \\
\text { estimated } 600 \text { years. A multi-proxy approach was used to document } \\
\text { changes in the physical, chemical and biological properties of the } \\
\text { sediments. We found evidence for a relatively mild period (mid/late } 15 \text { th } \\
\text { century to mid/late } 16 \text { th century) during the early part of the Little Ice Age } \\
\text { (LIA), characterized by high sedimentation rates and laminations. This was } \\
\text { followed by colder, drier and windier conditions corresponding to the } \\
\text { coldest phase of LIA and coinciding with the latest and most extensive } \\
\text { period of regional ice cap expansion (early } 16 \text { th to late } 19 \text { th centuries). A } \\
\text { rapid warming occurred at the beginning of the } 20 \text { th century. Variations in } \\
\text { titanium (Ti) content in the core, a proxy for detrital sediment inputs, } \\
\text { showed good agreement with reconstructed secular variations in summer } \\
\text { melt rates on Penny Ice Cap between mid } 14 \text { th century and the present- } \\
\text { day, providing supporting evidence for a climatic-hydrological connection } \\
\text { between the ice cap and Nettilling Lake. }\end{array}$ \\
\hline
\end{tabular}




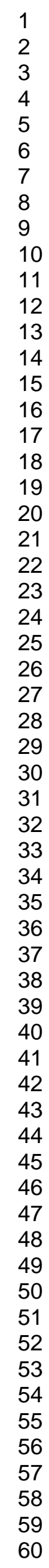

SCHOLARONE $^{\text {th }}$

Manuscripts

http://mc.manuscriptcentral.com/holocene 


\title{
PALAEOENVIRONMENTAL HISTORY OF THE LAST SIX CENTURIES IN THE NETTILLING LAKE AREA (BAFFIN ISLAND, CANADA): A MULTI- PROXY ANALYSIS
}

\author{
Anne Beaudoin, Reinhard Pienitz, Pierre Francus, Christian Zdanowicz and \\ Guillaume St-Onge.
}

The Baffin Island region in the eastern Canadian Arctic has recently experienced a rapid warming, possibly unprecedented in millennia. To investigate the response of freshwater environments to this warming and place it in a secular perspective, we analyzed a $80-\mathrm{cm}$ long sediment core from Nettilling Lake, the largest lake of the Canadian Arctic Archipelago. The core was taken from a part of the lake basin that receives meltwater and sediment inputs from the nearby Penny Ice Cap. The core time scale, established using ${ }^{137} \mathrm{Cs}$ and palaeomagnetic techniques, spans an estimated 600 years. A multi-proxy approach was used to document changes in the physical, chemical and biological properties of the sediments. We found evidence for a relatively $1 \mathrm{iD}$ period ( $\mathrm{mid} /$ late $15^{\text {th }}$ century to mid/late $16^{\text {th }}$ century) during the early part of the Little Ice Age (LIA), characterized by high sedimentation rates and laminations. This was followed by colder, drier and windier conditions corresponding to the coldest phase of LIA and coinciding with the latest and most extensive period of regional ice cap expansion (early $16^{\text {th }}$ to late $19^{\text {th }}$ centuries). A rapid warming occurred at the beginning of the $20^{\text {th }}$ century. Variations in titanium (Ti) content in the core, a proxy for detrital sediment inputs, showed good agreement with reconstructed secular variations in summer melt rates on Penny Ice Cap between the mid $14^{\text {th }}$ century and the present-day, providing supporting evidence for a climatichydrological connection between the ice cap and Nettilling Lake.

Keywords: Nettilling Lake, Penny Ice Cap, Baffin Island, lake sediments, palaeoclimate, Little Ice Age 


\begin{abstract}
Anne Beaudoin (anne.beaudoin.1@ulaval.ca) and Reinhard Pienitz (reinhard.pienitz@cen.ulaval.ca), Laboratoire de Paléoécologie Aquatique (LPA), Département de Géographie and Centre d'études nordiques (CEN) Pavillon AbitibiPrice, 2405 rue de la Terrasse, Université Laval, Québec, QC, Canada G1V 0A6.
\end{abstract}

Pierre Francus (pierre.francus@ete.inrs.ca), Institut national de la recherche scientifique, Centre Eau Terre Environnement (INRS-ETE), 490 de la Couronne, Québec, QC, Canada G1K 9A9 and Centre d'études nordiques (CEN) Pavillon Abitibi-Price, 2405 de la Terrasse, Université Laval, Québec, QC, Canada G1V 0A6.

Christian Zdanowicz (christian.zdanowicz@geo.uu.se), Department of Earth Sciences, Uppsala University, Villavägen 16, 75236 Uppsala, Sweden

Guillaume St-Onge (guillaume_st-onge@uqar.ca), Institut des sciences de la mer de Rimouski (ISMER), Paleomagnetism and Marine Geology Laboratory, Université du Québec à Rimouski, and GEOTOP, 310 allée des Ursulines, Rimouski, Québec, Canada, G5L 3A1. 


\section{Introduction}

High latitude ecosystems are particularly vulnerable to impacts of recent humaninduced climate change due to numerous positive feedback mechanisms (Overpeck et al., 1997; Everett and Fitzharris, 1998). Earlier spring snowmelt and declining lake and sea-ice cover extents, associated with decreasing surface albedo, result in increased exposure to, and absorption of, solar energy. Observed and predicted consequences of climate warming at high latitudes include higher air temperatures, modifications of the hydrological regime, permafrost degradation and melting of glaciers and ice caps (Pienitz et al., 2004; IPCC, 2013).

Evidence of recent warming in the Foxe Basin / southern Baffin Island region (Miller et al., 2013) includes a reduction of seasonal sea ice cover volume (Moore, 2006) and an increased rate of summer melting on terrestrial ice caps (Zdanowicz et al., 2012). Long instrumental climate records in the Canadian Arctic are very sparse. In the absence of such records, pollen, diatoms or other lake sediment properties can be used to reconstruct regional climate variations or the response of aquatic ecosystems to these variations. In particular, lakes are known to respond rapidly to environmental changes, such as variations in temperature (e.g., Pienitz et al., 2004). An increase of 
only a few degrees can profoundly change ice cover conditions, modify the lake dynamics and increase primary productivity (Wolfe and Smith, 2004; Hodgson and Smol, 2008). Numerous studies have shown that recent environmental changes experienced by northern lakes are without any analogues throughout the Holocene and beyond (e.g., Axford et al., 2009, Wolfe and Smith, 2004).

Nettilling Lake on south-central Baffin Island has the largest freshwater catchment in the Canadian Arctic Archipelago, and as such, is an interesting study site for understanding the impact of current climate change on Arctic lacustrine environments. In this paper, we present the first detailed reconstruction of the past environmental history of Nettilling Lake, developed using an innovative, multi-proxy approach that integrates physical, chemical and biological properties recorded in lake sediments. Our main goal was to document past environmental and hydro-climatic changes in Nettilling Lake. In addition, we compared the sedimentary record of Nettilling Lake with an ice-core based proxy record of summer warmth developed from nearby Penny Ice Cap (Grumet et al., 2001; Zdanowicz et al., 2012), which supplies abundant meltwater and sediments to the lake. 


\section{Study site}

Nettilling Lake $\left(66.51^{\circ} \mathrm{N}, 70.90^{\circ} \mathrm{W}\right)$ is located in the south-central part of southern Baffin Island, and has an estimated surface area of $5542 \mathrm{~km}^{2}$ (Figure 1). The maximum measured lake water depth is $132 \mathrm{~m}$, but most of the lake is less than $60 \mathrm{~m}$ deep (Oliver, 1964). With an estimated catchment area of 52,970 $\mathrm{km}^{2}$ (including the Amadjuak Lake catchment area), Nettilling Lake is the most extensive freshwater aquatic drainage system in the Canadian Arctic Archipelago. However, because of its remote location, it has received limited research attention, and little is known of its past environmental history (Jacobs et al., 1997).

\section{[insert Figure 1.]}

Like most Arctic lakes, Nettilling Lake has a low biological productivity, and its ice cover persists approximately from mid-September to mid-July (Oliver, 1964; and recent observations by the authors, 2010-2015). The lake can be subdivided into two main morphological regions separated by a line from Magnetic Point (north shore) to Caribou Point (south shore; Figure 1). The western region has a regularly shaped deep basin and shoreline, while the eastern region has more irregular basin and shoreline shapes and numerous islands. This subdivision coincides with the contact between two different geological settings: the lowlands on the western side of the 
lake basin are mostly composed of Palaeozoic carbonates (Hudson Platform), whereas the bedrock of the eastern side is mostly made up of low-relief granite and gneiss plateaus of Precambrian age belonging to the Canadian Shield (Blackadar, 1967). Both areas are covered by unconsolidated glacial drift. Nettilling Lake is located below the estimated regional maximum postglacial marine transgression limit ( $93 \mathrm{~m}$ above sea-level (asl.)), and was therefore likely submerged by marine waters of the post-glacial Tyrrell Sea about $6.7 \mathrm{ka} \mathrm{BP}$, following the retreat of the Laurentide Ice Sheet (Blake 1966; Dyke, 1979; Jacobs et al., 1997). The postglacial isostatic rebound eventually isolated the area from marine influence and allowed the establishment of a freshwater basin around 5 ka BP (Blake, 1966; Narancic et al., 2013).

Nettilling Lake drains to the west into Foxe Basin via the large Koukdjuak River ( 74 km long) (Figure 1). Main tributaries feeding into Nettilling Lake are Amadjuak Lake, located to the south, and the Isurtuq River to the northeast. Isurtuq River, which is fed by meltwater from Penny Ice Cap, is about $235 \mathrm{~km}$ long and splits into two channels about $7 \mathrm{~km}$ before entering into Nettilling Lake._About $30 \mathrm{~km}$ from the ice eap, the river intersects a deltaic complex formed at the former entry point of a long 
proglacial lake system. Together, these hydrographic features have, and probably continue to exert influence on sediment delivery into Nettilling Lake.

Penny Ice Cap $\left(6410 \mathrm{~km}^{2}\right)$ is a remnant of the Foxe Dome sector of the Wisconsinan Laurentide Ice Sheet (Fisher et al., 1998). Summer melt rates on the ice cap have been increasing irregularly since the mid- $19^{\text {th }}$ century, with the most recent acceleration after the 1980 s, and are presently as high as they have ever been through the Late Holocene (Zdanowicz et al., 2012). Inputs of glacial meltwater from Penny Ice Cap, highly charged with silt, create a large plume of suspended material in the eastern part of Nettilling Lake, which contrasts with the transparent waters of the western basin (Figure 2).

[insert Figure 2.]

\section{Material and methods}

\subsection{Sediment core collection}

Field work was conducted at Nettilling Lake during the summer of 2010. In this paper, we focus on results obtained from core Ni5-8, a 90-cm long core retrieved with a percussion corer at a water depth of $18.9 \mathrm{~m}$ in a small bay in the northeastern part of the lake $\left(66.67^{\circ} \mathrm{N} 69.92^{\circ} \mathrm{W}\right)($ Figure 1), using a handheld percussion corer (Aquatic 
Research Instruments). The maximum thickness of the sediments deposited at this site is presently unknown. The sampling site was chosen based on its location near the outlet of Isurtuq River, which provides favorable setting for the preservation of a climate@ulated record of detrital inputs from Penny Ice Cap glacial meltwater.

\subsection{Core analysis}

\section{Sedimentology and chemical analyses}

In the Laboratoire de Paléoécologie Aquatique (LPA) at Université Laval, one half of core Ni5-8 was sampled at $0.5 \mathrm{~cm}$ resolution and then freeze-dried during $48 \mathrm{~h}$. Organic matter $(\mathrm{OM})$ content was determined at 1-cm resolution (one sample out of two) on $0.3 \mathrm{~g}$ of dry sediment using loss-on-ignition (LOI) at $550{ }^{\circ} \mathrm{C}$ during $5 \mathrm{~h}$, following the method of Heiri et al. (2001). Grain size analyses were performed at 1cm resolution using a HORIBA laser diffraction analyzer at the Laboratoire de Géomorphologie et Sédimentologie at Université Laval. About $0.3 \mathrm{~g}$ of freeze-dried and OM-free sed Pent (removed by combustion) was mixed in $5 \mathrm{ml}$ of Calgon electrolytic solution (hexametaphosphate, $10 \%$ ). Prior to grain size measurements, each sample was exposed to unsounds for $2 \mathrm{~min}$ in order to break down aggregates. Statistical parameters of the grain size distribution (mean, median, skewness and 
sorting) were then calculated with the GRADISTAT v8.0 software using the geometric method of moments (Blott and Pye, 2001).

The remaining half-sectioned core was first analyzed for magnetic susceptibility at the Institut des Sciences de la Mer de Rimouski (ISMER) of the Université du Québec à Rimouski. Measurements were done every $\mathrm{cm}$ using a Bartington point sensor on a GEOTEK multi-sensor core logger. The same half-sectioned core was then analyzed for major and minor element geochemistry using an ITRAX core scanner at the Institut National de la Recherche Scientifique, Centre Eau Terre Environnement (INRS-ETE), Québec. This instrument uses X-ray fluorescence (XRF) to measure semi-quantitative fluctuations in geochemical elemental abundances (Croudace et al., 2006). Measurements were done at high-resolution intervals (100 $\mu \mathrm{m}$ with $30 \mathrm{~s}$ of exposure time, $30 \mathrm{kV}$ of voltage and $25 \mathrm{~mA}$ of current) using a molybdenum-source X-ray tube, and individual elemental profiles (in counts per seconds; cps) were normalized by the total counts (expressed in kcps) at the corresponding depths to eliminate the effects of variable water and OM content in the sediment core (Croudace et al., 2006). Profiles were smoothed with a running mean 
over $1000 \mu \mathrm{m}$ intervals. The scanner also produces a positive X-ray radiography (a proxy for core density) with a $100 \mu \mathrm{m}$ resolution.

Thin sections of core Ni5-8 were made according to methods described in Lamoureux (1994) to characterize and interpret the fine sedimentary structures. Slabs of sediment (18 cm-long x $2 \mathrm{~cm}$-wide x $0.7 \mathrm{~cm}$-deep) were sampled, submerged in liquid nitrogen and then freeze-dried for $48 \mathrm{~h}$. Samples were impregnated in a low viscosity resin under light vacuum. After $48 \mathrm{~h}$ in an oven at $80{ }^{\circ} \mathrm{C}$, slabs were cut with a $45^{\circ}$ angle into three blocks, from which polished thin sections were prepared.

\section{Dating}

In order to construct a depth-age model for core Ni5-8, two different approaches were combined: radiometric dating and palaeomagnetism. First, the cesium-137 $\left({ }^{137} \mathrm{Cs}\right)$ activity of the sediment was measured in the top $15 \mathrm{~cm}$ of core Ni5-8 by gamma-ray spectroscopy using a High Purity Germanium (HPGe) well detector system at the Laboratoire de Radiochronologie, Université Laval. The measurements were carried out at $1-\mathrm{cm}$ intervals from 0 to $30 \mathrm{~cm}$ depth. Radiocarbon $\left({ }^{14} \mathrm{C}\right)$ and lead $210\left({ }^{210} \mathrm{~Pb}\right)$ measurements were also performed, but results were not considered usable due to 
extremely low OM content and the predominance of sediment probably eroded from the crystalline bedrock beneath Penny Ice Cap (see supplementary file).

To develop the depth-age model beyond $15 \mathrm{~cm}$ core depth, we combined ${ }^{137} \mathrm{Cs}$ and palaeomagnetism. This method is based on the principle that under favorable conditions in aquatic environments, magnetic particles in the sediments can record the orientation and intensity of the geomagnetic field at the time of deposition, which can be estimated from geomagnetic models (e.g., Tauxe, 2010; Stoner and St-Onge, 2007). To measure changes in direction of the geomagnetic field, magnetic properties were measured at 1-cm intervals at the Laboratoire de Paléomagnétisme et Géologie Marine of ISMER (Rimouski, Québec), using a 2 G Enterprises ${ }^{\mathrm{TM}} 755$ cryogenic $^{2}$ magnetometer on 3 U-channels $\left(4 \mathrm{~cm}^{2}\right)$. Because the core had been already subsampled for thin sections, a few sections of the U-channels were not completely filled with sediment. To minimize errors in measurements, U-channels were overlapped and data were removed from the dataset where duplication of U-Channel sampling intervals was not possible (gaps in Figure 3). The Natural Remanent Magnetization (NRM) was measured using alternating field (AF) demagnetization steps from 0 to $75 \mathrm{mT}$ ( $5 \mathrm{mT}$ increments). The magnetic inclination in the sediment was computed by principal component analysis (PCA) using AF demagnetization 
steps from 15 to $75 \mathrm{mT}$ (Mazaud, 2005). The maximum angular deviation (MAD) values were also computed and used as indicators of the quality of the palaeomagnetic data.

\section{Biological analyses}

In the Laboratoire de Paléoécologie Aquatique (LPA), fossil diatoms preserved in core Ni5-8 were extracted with hydrogen peroxide $\left(30 \% \mathrm{H}_{2} \mathrm{O}_{2}\right)$ digestion techniques and mixed with marker microspheres $\left(1.57 \times 10^{6}\right.$ microspheres $\left.\mathrm{ml}^{-1}\right)$. Microscope slides were mounted using Naphrax, a highly refractive synthetic resin (Battarbee et al., 2002). A minimum of 300 to 500 diatom valves were counted and identified for each subsample according to their concentration. Where diatoms were less abundant, 300 valves were identified or 1000 microspheres were counted. Identification of diatom species was made using a Leica DMRB microscope at 1000x magnification under oil immersion. The main taxonomic keys used were Fallu et al. (2000), Krammer \& Lange-Bertalot (1986, 1988, 1991a, b) and Antoniades et al. (2008).

\section{Statistical analyses}

PCA Chronological cluster analysis was performed on down-core profiles of normalized chemical element abundances, LOI, and water content to detect common patterns of variations in these data. Subsequently, chronological cluster analysis was 
also performed on the same data. Data were first standardized and transformed in Euclidean distance, and the clustering results were used to divide core Ni5-8 into distinct stratigraphic zones. The number of significant zones was determined using the broken stick model (Birks, 2012). Geochemical data were transformed from depth (cm) to age (year) scale using the developed age model (see section 4.2) in order to facilitate comparisons with other records. Correlation coefficients $(R)$ between different profiles of chemical elements were computed on the normalized data. Serial autocorrelations in the data were taken into account, and reduced degrees of freedom were used in order to test the significance of the observed correlations (Ebisuzaki, 1997).

\section{Penny Ice Cap data \\ A proxy record of past summer warmth was developed from ice cores drilled at the summit of Penny Ice Cap (67.25N, $65.77^{\circ} \mathrm{W}, ~-1860 \mathrm{~m}$ a.s.1.) in 1995 and 2010 (Grumet et al., 2001; Fisher et al., 2011; Zdanowicz et al., 2012). The proxy used is the volumetric percentage of "melt features" (MF \%) in the cores, which are distinct, bubble-poor layers or lenses of ice formed by the refreezing of surface meltwater into underlying firn. Koerner (1977) first established that the relative abundance of these features is correlated to past summer warmth conditions. The composite MF record}


developed from Penny Ice Cap cores covers the period 1695 to 1992 AD at 5 to 10 year resolution, and extends to -3300 years ago, but with a 25 -year resolution only. For the period considered in this paper, i.e. the past 6 centuries, the possible dating error in the Penny Ice Cap chronology is estimated to be $<10 \%$ of true age (Zdanowicz et al., 2012).

\section{Results}

\subsection{General-core-description}

Visual and X ray examination of core Ni5-8 revealed diffuse, dark yellowish brown

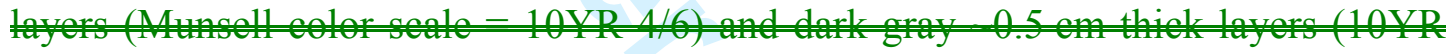

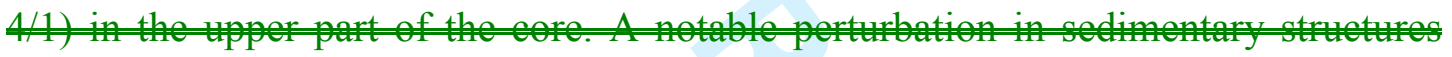
(very diffuse layer boundaries) was found in the middle part of the core $(-17$ to $47 \mathrm{~cm})$. The lower part ( 60 to $90 \mathrm{em})$ is also-characterized by seval black diffuse layers $(-2 \mathrm{~mm}$ to $5 \mathrm{~mm})$. Neither disontinuities nor erosion strfaces were observed in thin sections and X adiographies. 


\subsection{Development of core chronology}

The chronology of core Ni5-8 was developed using ${ }^{137} \mathrm{Cs}$ and palaeomagnetic secular variations (PSV) correlated with geomagnetic field model outputs. Such a combination of techniques has been successfully applied for dating marine and lake sediments at other sites in the Canadian Arctic (e.g., Barletta et al., 2010a, Antoniades et al., 2011, Cook et al, 2009). The ${ }^{137} \mathrm{Cs}$ profile presents a well-defined peak at $6.25 \mathrm{~cm}$, which is attributed to the year $1963 \mathrm{AD}$ when maximum atmospheric fallout of ${ }^{137} \mathrm{Cs}$ from pre-moratorium surface nuclear weapon tests was attained (Figure 3A) (Appleby, 2001). The ${ }^{137}$ Cs peak is sharp, which suggests negligible vertical mixing in the sediments.

\section{[insert Figure 3.]}

Geomagnetic inclination variations were used to define the core chronology below 15 cm depth (Figure 3). Inclination values oscillate around the geocentric axial dipole (GAD) $\left(77.8^{\circ} \mathrm{N}\right.$ for Nettilling Lake) and very low maximum angular deviation (MAD) values were obtained (below $5.4^{\circ}$, with a mean of $2.3^{\circ}$ ), which indicate highquality directional data (Stoner and St-Onge, 2007). An initial chronology was first developed for the entire core Ni5-8 assuming a constant sedimentation rate based on 
${ }^{137} \mathrm{Cs}$ peak. The inclination profile was then compared to several model reconstructions of past global geomagnetic field variations for the location of Nettilling Lake using the AnalySeries 2.0.4 software (Paillard, 2006) to provide further chronological constraints (Figure 3). We used the Cals3k.4 model that spans the past 3000 years (Korte and Constable, 2011), as well as the GUMF1 model which extends back to 1590 AD (Jackson et al., 2000). In addition, we compared the Ni5-8 inclination record to the Eastern Canadian Stack, a ${ }^{14} \mathrm{C}$-constrained compilation of marine palaeomagnetic directional and palaeointensity records (Barletta et al., 2010b).

Correlations between the Ni5-8 palaeomagnetic profile and these various datasets were established using 6 tie points labelled_a to $f$ in Figures 3 and Table 1. A highly significant correlation was found between the Ni5-8 inclination series and the Cal3k.4 model output for the Nettilling Lake region $(\underline{R}=0.74, \underline{p \text {-value }}=0.0147, \alpha=0.05)$. The inclination profile of core Ni5-8 was also highly correlated with the GUMF1 model for the region $(\underline{R}=0.77, \underline{p-v a l u e}=<0.01, \alpha=0.05)$.

Table 1. Correlated tie points with the Cals3k.4 (Korte and Constable, 2011), GUMF1 (Jackson et al., 2000) models and the Eastern Canadian stack (Barletta et al., 2010b) associated with depth in core Ni5-8.

\begin{tabular}{ccccc}
\hline Cals3k.4 & GUMF1 & $\begin{array}{c}\text { Eastern Canadian } \\
\text { stack }\end{array}$ & $\begin{array}{c}\text { Estimated } \\
\text { mean age }\end{array}$ & Depth (cm) \\
\hline
\end{tabular}




\begin{tabular}{lccccc}
\hline & & & & (AD) & \\
\hline $\mathbf{a}$ & 1980 & 1984 & - & 1982 & 4 \\
$\mathbf{b}$ & 1850 & 1842 & - & 1846 & 25 \\
$\mathbf{c}$ & 1610 & 1625 & - & 1617.5 & 49 \\
$\mathbf{d}$ & - & - & 1541 & 1541 & 66 \\
$\mathbf{e}$ & - & - & 1492 & 1492 & 77 \\
$\mathbf{f}$ & - & - & 1450 & 1450 & 82 \\
\hline
\end{tabular}

The age-depth model developed by combining ${ }^{137} \mathrm{Cs}$ and palaeomagnetic data gives an estimated bottom age for core Ni5-8 in the early 14th century, at 1362 AD (Figure 4). The time interval recorded in core Ni5-8 therefore spans much or most of the Little Ice Age (LIA) cold climate interval, which, on the basis of various palaeoclimatic proxies, is estimated to have lasted from the mid-/late 13th to the 19 th century in the eastern Canadian Arctic (Grumet et al., 2001; Moore et al., 2001; Briner et al., 2009; Kaufman et al., 2009; Rolland et al., 2009; Thomas and Briner, 2009; Miller et al. 2012; Margreth et al., 2014).

Our age-depth model for core Ni5-8 yields sedimentation rates ranging from 0.10 to $0.26 \mathrm{~cm} \mathrm{a}^{-1}$ over the past $\sim 600$ years, with an average of $0.15 \mathrm{~cm} \mathrm{a}^{-1}$, close to the one $\left(0.13 \mathrm{~cm} \mathrm{a}^{-1}\right)$ obtained from the ${ }^{137} \mathrm{Cs}$ peak.

In order to estimate the possible error of the age model for Nettilling Lake core Ni 58, a Markov chain Monte Carlo procedure was employed to simulate stochastic variations in sedimentation rates between pairs of chronostratigraphic markers. The 
method adopted here shares similarities with the Bayesian approach of Blaauw and Christen (2011), but differs in some respects. In Blaauw and Christen's method, sedimentation is assumed to follow an autoregressive gamma function, the parameters of which must be estimated a priori. In our approach, rather than imposing a defined probability function (PDF), we used Holocene sedimentation data series from proglacial lakes on Baffin Island as models, based on the assumption that sedimentation in Nettilling Lake shares the same type of PDF (whatever it may be) and spectra of temporal variations. Such assumptions are plausible, even if sedimentation rates differ between lakes. The template data used originate from Donard Lake on southeastern Baffin Island (Moore et al., 2001), and from Big Round Lake on northeastern Baffin Island (Thomas and Briner, 2009). In an iterative procedure, randomly-selected subsets of these data were used to generate surrogate series of stochastic sedimentation rate variations with the same PDF and temporal spectra as the template series, but with different (prescribed) means. The Iterative Amplitude Adjusted Fourier Transform (IAAFT) algorithm of Schreiber and Schmitz (1996) was used to generate thousands of surrogate series, from which the possible range of corresponding ages between chronostratigraphic markers was estimated. The procedure implicitly takes into account autocorrelation in the data series to the extent 
that it partly defines their temporal spectra. We also accounted for the possible age uncertainties on the various marker horizons, which were conservatively estimated to range between \pm 20 years $(2 \sigma)$ for the ${ }^{137}$ Cs-dated 1963 layer, to \pm 50 years $(2 \sigma)$ for marker horizons dated by palaeomagnetism. In the latter case, the age uncertainty reflects possible errors in the estimated correlative depths with the Cals $3 \mathrm{k} .4$ or GUMFI models, or with the Eastern Canadian Stack, or ${ }^{14} \mathrm{C}$ uncertainties in the data used to constrain these models. The resulting estimated error range for the age model of core $\mathrm{Ni} 5-8$, as determined by the procedure described above, is shown as gray shading in Figure 4. The width of the shaded envelope corresponds to the outer bounds of the $95 \%$ confidence interval, and the broken line is the median age estimate of the sediment layers. The largest dating error, found at mid-depth between horizons $\mathrm{b}$ and $\mathrm{c}(\sim 38 \mathrm{~cm})$, is estimated to be \pm 110 years.

[insert Figure 4.] 


\subsection{Stratigraphy and sedimentology}

\section{General core description}

\subsection{General core description}

Visual and X-ray examination of core Ni5-8 revealed diffuse, dark yellowish brown layers (Munsell color scale $=10 \mathrm{YR} 4 / 6$ ) and dark gray $\sim 0.5 \mathrm{~cm}$ thick layers (10YR 4/1) in the upper part of the core. A notable perturbation in sedimentary structures (very diffuse layer boundaries) was found in the middle part of the core $(\sim 17$ to

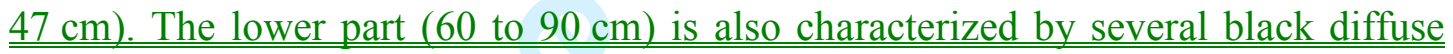
layers $(\sim 2 \mathrm{~mm}$ to $5 \mathrm{~mm})$. Neither discontinuities nor erosion surfaces were observed in thin sections and X-radiographies.

The lithostratigraphy of core Ni5-8 was divided into 4 zones of distinctive sedimentological and geochemical features. Profiles of the sedimentological characteristics within these zones are shown in Figure 5, and are described below, starting with the bottom of the core.

Zone I $(90-78.9 \mathrm{~cm})$

The $\mathrm{OM}$ in this zone varies from 1.5 to $4 \%$, with a mean of $2.6 \%$ (Figure $5 \mathrm{~B}$ ). Magnetic susceptibility is at its maximum $\left(234 \times 10^{-5} \mathrm{SI}\right)$ near the bottom of the core, and decreases upwards through the zone to reach $38 \times 10^{-5} \mathrm{SI}$ (Figure 5C). These high 
values are coupled to relatively coarse particle sizes, and the presence of abundant large grains $(250-1000 \mu \mathrm{m})$ of feldspar and quartz found sporadically in the finer matrix. These particles are presumed to be transported by wind and deposited on the lake ice-cover during winter, and we refer to them as niveo-aeolian grains (Figure $5 \mathrm{H})$. The sedimentary matrix in zone $\mathrm{I}$ is mainly composed of medium silt to fine sand $(>60 \%$ between $30-130 \mu \mathrm{m})$ (Figure 5D). The median grain size decreases upward through the zone from $130 \mu \mathrm{m}$ to $18 \mu \mathrm{m}$. The grain size distribution is poorly sorted (index of 3.2 to 4.1 ), but only slightly skewed $(-0.9<$ skewness $<-0.1)$, implying that the mean of the distribution is close to its median. Examination of thin sections did not reveal any remarkable sedimentary structures in this zone, other than the sporadic presence of niveo-aeolian grains (Figure $5 \mathrm{H}$ ).

[insert Figure 5.]

\section{Zone II $(78.9-57.9 \mathrm{~cm})$}

The relatively high sediment density in this zone, which shows as dark gray shades on the X-radiography, is linked to relatively low water content, decreasing upwards from $\sim 30$ to $20 \%$ (Figure 5A). Magnetic susceptibility and OM content also decrease upwards (Figures 5B-C). The transition from zone I to II is clearly distinct in the particle size distribution and magnetic susceptibility graphs (Figures 5C-D). The 
grain size distribution shifts towards a median of $\sim 35 \mu \mathrm{m}$, while the mean grain size varies between 22 and $45 \mu \mathrm{m}$ (silt $>75 \%$ ). Except for one sample at $76 \mathrm{~cm}$, the particle size distribution is symmetrical $(-0.2 \leq$ skewness $\leq 0.8)$ and moderately sorted (index $\sim 2$ ). Diffuse layers are observed in thin sections, as well as an important decrease in the number of niveo-aeolian grains relative to zone I (Figure 5H). The estimated mean sedimentation rate in zone II is $0.23 \mathrm{~cm} \mathrm{a}^{-1}$ (Figure 4).

\section{Zone III (57.9 - $14.6 \mathrm{~cm})$}

The X-radiography for this zone suggests a low sediment density relative to zones I and II, which also corresponds with a higher water content (27 - $45 \%$ ) (Figure 5A). The grain size distribution in the lower part of the zone $(47-58 \mathrm{~cm})$ is variable (median between $20-54 \mu \mathrm{m}$ ) and the sedimentation rate relatively high $\left(0.26 \mathrm{~cm} \mathrm{a}^{-1}\right)$, whereas the grain size distribution is more constant from 47 to $14.6 \mathrm{~cm}$ (median from 26-38 $\mu \mathrm{m})$ and the sedimentation rate is lower $\left(0.10 \mathrm{~g} \mathrm{~cm}^{-2} \mathrm{a}^{-1}\right)$ than in underlying sediments (Figure 4). Sorting is similar to that in zone II, the index varying from 1.9 to 2.7. Apart from sporadic niveo-aeolian grains, the main distinguishing structural feature of zone III is the notable presence of $\underline{i n \text {-situ }}$ perturbation features (distorted layers) observed in the thin sections (Figure 5H). 


\section{Zone IV (14.6 - $0 \mathrm{~cm})$}

The OM content in zone IV decreases upward from 1.1 to $0.04 \%$ (Figure 5B). The median grain size varies between 20 and $30 \mu \mathrm{m}$, which are the smallest median values in the entire core. Sediment in zone 4 is mainly composed of silt at $>80 \%$. Laminations are visible in thin sections, with thickness ranging from 0.3 to $3 \mathrm{~mm}$, but more commonly between 0.5 and $1.5 \mathrm{~mm}$ (Figure $5 \mathrm{H}$ ). These laminations consist of alternating finer and coarser silt layers, but the irregular and disturbed nature of laminae does not allow for an unambiguous classification as varves (i.e., annual deposits). Furthermore, counting couplets of laminae from the top of the core (2010) down to the ${ }^{137}$ Cs peak (1963) only yielded approximately half of the expected total of 47 years. No niveo-aeolian grains were found in thin sections; however, some fecal pellets $(\sim 0.2$ to $0.6 \mathrm{~mm})$ were observed.

\subsection{Geochemistry}

A total of 27 elements were measured in core Ni5-8. However, only silicon (Si), potassium $(\mathrm{K})$, calcium $(\mathrm{Ca})$, titanium $(\mathrm{Ti})$, iron $(\mathrm{Fe})$, rubidium $(\mathrm{Rb})$, strontium $(\mathrm{Sr})$ and zirconium $(\mathrm{Zr})$ are discussed in this paper because other elements presented noisy profiles near the limits of detection. Coefficients of correlation $(\underline{R})$ were computed 
between down-core variations in these elements in order to identify significant geochemical associations between them (Table 2). Strong positive correlations were found between $\mathrm{Si}, \mathrm{Ti}, \mathrm{K}, \mathrm{Ca}$ and $\operatorname{Sr}(0.73 \leq \underline{R} \leq 0.91, \underline{p \text {-value }}=<0.01, \alpha=0.05)$.

Table 2. Correlation coefficients $(\underline{R})$ calculated for linear regressions between geochemistry data recorded in core Ni5-8.

\begin{tabular}{lllllllll}
\hline & $\mathbf{S i}$ & $\mathbf{K}$ & $\mathbf{C a}$ & $\mathbf{T i}$ & $\mathbf{F e}$ & $\mathbf{R b}$ & $\mathbf{S r}$ & $\mathbf{Z r}$ \\
\hline $\mathbf{S i}$ & 1 & & & & & & & \\
$\mathbf{K}$ & 0.901 & 1 & & & & & & \\
$\mathbf{C a}$ & 0.863 & 0.850 & 1 & & & & & \\
$\mathbf{T i}$ & 0.731 & 0.849 & 0.626 & 1 & & & & \\
$\mathbf{F e}$ & 0.377 & 0.477 & 0.134 & 0.603 & 1 & & & \\
$\mathbf{R b}$ & 0.336 & 0.493 & 0.401 & 0.413 & 0.094 & 1 & & \\
$\mathbf{S r}$ & 0.770 & 0.676 & 0.808 & 0.476 & 0.034 & 0.557 & 1 & \\
$\mathbf{Z r}$ & 0.158 & 0.209 & 0.389 & 0.033 & - & .0518 & 0.436 & 1 \\
& & & & & 0.288 & & & \\
\hline
\end{tabular}

In view of the dominant lithologies in the eastern part of the Nettilling Lake watershed (granites and gneisses), we consider that these 5 elements are good indicators of detrital inputs into the lake.

The Si/Ti ratio is commonly used as a proxy for biogenic silica (Rothwell and Rack, 2006). However, considering the high correlation between $\mathrm{Ti}$ and $\mathrm{Si}(\underline{R}=0.73, \underline{p}$ $\underline{\text { value }}=<0.01)$ in core Ni5-8, the predominantly crystalline bedrock geology of the 
region, and the low amount of biogenic silica (see section 4.4 below) to-significantly influence the $\mathrm{Si} / \mathrm{Ti}$ ratio in the sediments, we suggest it is more likely that $\mathrm{Si}$ concentrations in Nettilling core Ni5-8 are controlled by inorganic silica inputs.

Variations in the $\mathrm{Zr} / \mathrm{K}$ ratio (Figure $5 \mathrm{~F}$ ) in the core follow those in the particle size profile. Generally, $\mathrm{Zr}$ is associated with weathering-resistant, coarse mineral particles such as zircon $\left(\mathrm{ZrO}_{2}\right)$, and $\mathrm{K}$ with less resistant, and therefore usually finer particles (feldspars and clay minerals), thus the $\mathrm{Zr} / \mathrm{K}$ ratio is a good proxy for relative particle size (Cuven et al., 2010), which is confirmed by the particle size distribution (Figure $5 \mathrm{D})$.

\subsection{Diatom stratigraphy}

The biostratigraphy of core Ni5-8 was divided into 3 zones of distinctive limnological features. These zones are shown in Figure 6, and are described below, starting with the bottom of the core.

Diatoms below $65 \mathrm{~cm}$ in core Ni5-8 are found in extremely low concentration and they are highly fragmented, presenting signs of erosion and dissolution (Figure 6). 
Few fragments could be identified as taxa belonging to the freshwater genera Eunotia

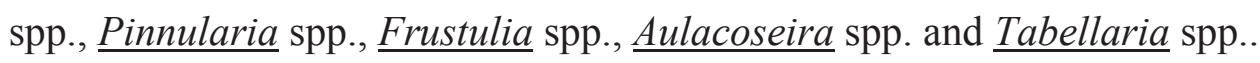

In zone $\mathrm{A}$, from $65 \mathrm{~cm}$ to $47.5 \mathrm{~cm}$ depth, diatoms are still found at low concentration, but are less fragmented and eroded than below. Most taxa that could be identified belong to the freshwater genera Fragilaria, Tabellaria, Eunotia, Brachysira and Pinnularia. Diatoms appear to be better preserved in zone B, starting at $47 \mathrm{~cm}$ depth

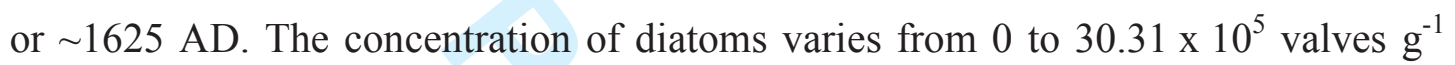
dry sediment. Of a total of 158 different taxa identified in core Ni5-8, only 83 have relative abundances $>1 \%$, and 41 have abundances $>2 \%$. The latter represent at least $79 \%$ of the diatoms identified in each sample. Most benthic diatoms identified in this zone belong to the genera Eunotia, Brachysira, Cavinula, Frustulia and Pinnularia, which are typically associated with circumneutral to slightly acidic and low-electrolyte waters, as well as with dystrophic bog environments (Krammer and Lange-Bertalot, 1986, 1991a, b; Fallu et al., 2000; Pienitz, 2001; Antoniades et al., 2008). Zone $\mathrm{C}$ (after $\sim 1911 \mathrm{AD}$ ) is characterized by a decrease in taxa belonging to these genera, and concurrent with increases in $\underline{\text { Psammothidium }}$ spp. and Tabellaria flocculosa.

[insert Figure 6.] 


\section{Discussion}

\subsection{Nettilling Lake palaeoenvironments}

Zone I (Early LIA: mid- $14^{\text {th }}$ century to $\mathrm{mid} /$ late $15^{\text {th }}$ century)

The characteristics of the lowermost zone I in core Ni5-8 suggest that sedimentary processes in Nettilling Lake during the $14^{\text {th }}$ and $15^{\text {th }}$ centuries were completely different from those that prevailed later. Compared to the other three zones, the relatively coarse particle size, and the abundance of niveo-aeolian grains are indicative of sediment inputs from proximal sources. Considering the low catchment topography, it is plausible that the drainage network feeding into Nettilling Lake was different than at the present. A possible greater inflow of water draining the carbonate terrain in zone 1 , relative to zone 2, is plausible, although speculative, spectate that prior to the late 15 th century, the dominant inflow to Nettilling Lake originated from Amadjuak Lake located to the South, which drains limestone terrain. This will have likely raised the the pH of lake waters to above 7, which could-and could explain the poor diatom frustule preservation prior to the mid/late $16^{\text {th }}$ century, an observation often reported from alkaline Arctic lake sediments (Flower, 1993; Ryves et al., 2009). 
Zone II (Warm phase of LIA: mid/late $15^{\text {th }}$ century to mid/late $16^{\text {th }}$ century)

The relatively high mean sedimentation rate $\left(0.23 \mathrm{~cm} \mathrm{a}^{-1}\right)$ and the presence of laminations throughout this zone are characteristics usually associated with mild warmer climatic conditions in Arctic lake sediment records (Hughen et al., 2000; Moore et al., 2001; Lamoureux and Gilbert, 2004). Some changes in sediment transfer could have eceuredoccurred in the Isurtuq river between zone I and II, such that discharge of silty sediment in the bay where the cores were obtained increased, thereby reducing the mean grain size (in zone II). Thomas and Briner (2009) provide evidence for a warming period during the LIA that lasted from 1375 to $1575 \mathrm{AD}$ in varved sediments from Big Round Lake (northeastern Baffin Island) (Figure 7). We postulate that during this milder-warmer interval, the rate of glacial meltwater discharge from Penny Ice Cap into the Isurtuq River increased substantially, and this is indirectly supported by glaciological evidence (see section 5.2 ). Once the sediment storage capacity along the Isurtuq River was exceeded, \#ntil a threshold was reached at which downstream sediment transport was no longer impeded by the proglacial delta located at $30 \mathrm{~km}$ distance from the ice cap. At this point, the inflow of silty glacial meltwaters into Nettilling Lake via the Isurtuq River would have increased 
significantly. However, this new inflow apparently did not lower lake water $\mathrm{pH}$ sufficiently to allow for good diatom frustule preservation.

[insert Figure 7.].

Zone III (Late cold phase of LIA: mid/late $16^{\text {th }}$ century to early $20^{\text {th }}$ century) Sediment laminations rendered visible through X-radiographs in this part of the core are not recognizable in thin-sections. This may be due to some bioturbation, coupled with decreasing sedimentation rates after $\sim 1600$ AD (Figure 4). With lower sedimentation rates, water circulation or small benthic organisms can more easily disturb the water-sediment interface. The abundant niveo-aeolian grains found in zone III are generally associated with the presence of expanded lake ice cover, high surface wind velocities and/or reduced snow accumulation in the catchment basin (Lewis et al., 2002; Lamoureux and Gilbert, 2004). Winds capable of entraining coarse sediments such as niveo-aeolian grains are usually more frequent during cold and dry climatic periods. More numerous sand particles can be trapped in cracks during a longer period when ice is covering the lake; and stronger winds also favor the formation of such lake ice cracks (Vologina et al. 2005). Lamoureux and Gilbert (2004) observed a relative increase in the abundance of coarse grains between 1350$1750 \mathrm{AD}$ in the sedimentary record from Bear Lake (Devon Island). These 
considerations suggest that zone III in the Nettilling Lake Ni5-8 record is associated with a period of relatively cool, dry and windy climatic conditions, which may correspond to the coldest phase of the LIA. Sedimentary, palaeolimnological and glaciological records indicate that in the eastern Canadian Arctic, the LIA spanned an extended period between the 13th and 19th centuries (Grumet et al., 2001; Moore et al., 2001; Briner et al., 2009; Kaufman et al., 2009; Rolland et al., 2009; Thomas and Briner, 2009; Miller et al., 2012). Moreover, compiled lichenometric ages and radiocarbon dates on fossil vegetation exhumed from beneath Canadian Arctic ice caps bracket several late Neoglacial episodes of ice cap expansion on southern Baffin Island, the latest and most extensive beginning ca. $1500 \mathrm{AD}$ and ending in the mid- to late 19th century (Miller et al., 2012; Margreth et al., 2014). We suggest that zone III in core Ni5-8 represents sedimentation during part of this latest interval, which was also characterized by reduced inputs of glacial meltwater into Nettilling Lake, presumably owing to colder conditions and reduced summer snow/ice melt (see also section 5.2 below). This could also explains the apparent increase in LOI in zone IIIIn fact, LOI might not be inereasing, it is probably, which may just the-result fromef lower inputs of detrital sediment due to colder conditions and less-reduced meltwater inputs. We further postulate that by that time, the $\mathrm{pH}$ in Lake Nettilling water had 
dropped below 7 , allowing the preservation of diatoms in the sediments. The greater diatom diversity during this period (Figure 6) likely resulted from reduced water turbidity, greater water column transparency and stability, and hence deeper light penetration during the short summer ice-free period in the lake and the Isurtuq River. The diatom accumulation rate might not be highest during Zone III, as increased absolute diatom abundance values during this zone may be a function of reduced sediment inputs (as reflected by higher LOI). The diatom assemblage found in this zone is mostly composed of benthic circumneutral to acidophilic taxa (e.g., $\underline{\text { Brachysira procera, }}, \underline{\text { Cavinula cocconeiformis, }}, \underline{\text { Frustulia saxonica }}$ and $\underline{\text { Pinnularia }}$ spp.) that are usually found in wetlands rich in Sphagnum moss habitats (Krammer and Lange-Bertalot, 1986, 1991a, b; Fallu et al., 2000; Pienitz, 2001; Antoniades et al., 2008). Thus, their abundance could reflect the presence of extensive moss mats that may have covered the banks of the Isurtuq River at a time of reduced inflow (Figure 2).

\section{Zone IV (after the early $20^{\text {th }}$ century)}

The abrupt transition from zones III to IV in core Ni5-8 indicates that conditions in Nettilling Lake changed markedly in the early $20^{\text {th }}$ century. These changes are reflected in many sediment properties such as grain size, magnetic susceptibility and 
diatom assemblage composition (Figures 5-6). The mean sedimentation rate in the lake had apparently increased earlier, possibly as early as the mid-19th century (Figure 4). This timing agrees well with the inferred termination of the LIA as documented in other regional proxy records (Rolland et al., 2009; Margreth et al., 2014). Rising temperatures would have caused increased seasonal snow and ice melt rates and detrital sediment delivery into the lake (see also section 5.2 below). Positive correlations between air temperature and sedimentation rates have been documented in several Canadian Arctic lakes (Hughen et al., 2000; Moore et al., 2001; Lamoureux and Gilbert, 2004). Rapid sedimentation flux reduces the potential for bioturbation and may explain the better preservation of laminated sediment structures in the upper part of the Nettilling Lake core Ni5-8. It is also noteworthy that the increase in Ti concentration in the core in the early $20^{\text {th }}$ century coincides, within possible dating errors, with a marked increase in the thickness of varves in the sediment records of Upper Soper Lake (southern Baffin Island; Hughen et al., 2000), Bear Lake (Devon Island; Lamoureux and Gilbert, 2004) and Big Round Lake (eastern Baffin Island; Thomas and Briner, 2009) reflecting a rise in regional air temperatures (Figure 6). The changes observed in floral composition in core Ni5-8 closely mirror those displayed in the sedimentological and geochemical proxies. More competitive genera, 
such as Tabellaria, Achnanthes and Psammothidium, progressively replaced the benthic acidophilic taxa found before the $20^{\text {th }}$ century, probably due to reduced light penetration in Nettilling Lake as silty meltwater inflows from Penny Ice Cap increased via the Isurtuq River.

\subsection{Comparison with the Penny Ice Cap summer melt record}

To further investigate the hydrological connection between sedimentation in eastern Nettilling Lake and glacial melt rates on southern Baffin Island, we compared the profile of Ti abundance obtained from core Ni5-8 with a proxy record of past summer warmth developed from ice cores drilled at the summit of Penny Ice Cap $\left(67.25^{\circ} \mathrm{N}\right.$, $65.77^{\circ} \mathrm{W}, \sim 1860 \mathrm{~m}$ a.s.1.) in 1995 and 2010 (Grumet et al., 2001; Fisher et al., 2011; Zdanowicz et al., 2012). The proxy used is the volumetric percentage of 'melt features" (MF \%) in the cores, which are distinct, bubble-poor layers or lenses of ice formed by the refreezing of surface meltwater into underlying firn. Koerner (1977) first established that the relative abundance of these features is correlated to past summer warmth conditions. The composite MF record developed from Penny Ice Cap cores covers the period 1695 to $1992 \mathrm{AD}$ at 5 to 10 -year resolution, and extends to $\sim 3300$ years ago, but with a 25 -year resolution only. For the period considered in this paper, 
i.e. the past 6 centuries, the possible dating error in the Penny Ice Cap chronology is estimated to be $<10 \%$ of true age (Zdanowicz et al., 2012).

To facilitate comparison of multi-decadal trends, the time series of Ti abundance in core Ni5-8 and the Penny Ice Cap MF record were both smoothed with a 30-year running mean. This was done in part to mitigate the possible time-averaging effect of deep water percolation on the Penny Ice Cap MF \% record, ${ }_{2}$-which may result in the apparent age of MF variations in this record being earlier (younger) than the variations in summer warmth that caused them. Given that the summit of Penny Ice Cap, where the MF\% record was developed, is situated more than $1830 \mathrm{~m}$ above the Nettilling Lake basin ( $30 \mathrm{~m}$ asl.), some altitude-dependent time lag may also be expected between the responses of the ice cap summit and the lake to regional temperature changes.

The smoothed time series of Ti content in Nettilling Lake core Ni5-8 and of MF\% on Penny Ice Cap were found to correlate positively over the common interval 1695 $1992 \mathrm{AD}(\underline{R}=0.45, \underline{p \text {-value }}=0.0579 ; \alpha=0.05)$, with the strength of the correlation increasing after the mid- $19^{\text {th }}$ century $(\underline{R}=0.63, \underline{p \text {-value }}=0.011$; Figures $7, \mathrm{~A}-\mathrm{B})$. The earlier part of the Penny Ice Cap MF\%, although with a limited 25-year resolution, also shows a general agreement with the pattern of variations seen in the Nettilling 
Lake Ti record from mid- $14^{\text {th }}$ century to late $17^{\text {th }}$ century. The good correspondence between these two records supports our hypothesis that changes in Ti concentrations in sediments of eastern Nettilling Lake are modulated, on multi-decadal to secular time scales, by the supply of silty glacial meltwater from Penny Ice Cap via the Isurtuq River. During colder periods associated with reduced summer Penny Ice Cap melt rates, the supply of fine glacigenic sediments to the lake is presumably reduced, whereas during periods of increased summer melt rates the supply of these sediments to the lake increases.

Some secular changes in melt rates of Penny Ice Cap appear to be offset by a few decades relative to the presumed corresponding changes in Ti abundance in core Ni58. For example, the initial rise in MF\% of Penny Ice Cap at the end of the LIA occurred between $\sim 1860$ and $1890 \mathrm{AD}$, whereas $\mathrm{Ti}$ concentrations in eastern Nettilling Lake sediments increased later, on $\square$ after 1900 AD. The mismatch could be due to age model inaccuracies in one or the other (or both) records (see Figure 4). It could also imply that melt rates on Penny Ice Cap must exceed some threshold for a sedimentological response to be registered in the Nettilling Lake sediment record. This threshold might conceivably vary over time as a function of the channel 
morphology, sediment storage capacity, and drainage configuration of the Isurtuq River, as discussed earlier.

\section{Summary and conclusions}

Using multiple proxies, we developed a 600-year long, high-resolution palaeoenvironmental record from a sediment core taken in Nettilling Lake on Baffin Island, at the centre of a vast and remote understudied region of the Canadian Arctic Archipelago. We used an unconventional approach in palaeolimnology to establish the core chronology by combining radiometric $\left({ }^{137} \mathrm{Cs}\right)$ and palaeomagnetic dating techniques, which allowed us to date the bottom of the $90-\mathrm{cm}$ long core to the mid $14^{\text {th }}$ century. This finding implies a relatively high mean sedimentation rate $(\sim 0.15$ $\mathrm{cm} \mathrm{a}^{-1}$ ) for an Arctic lake.

Our sedimentary record from Nettilling Lake spans most of the LIA cold interval (mid-13th to 19th centuries). It contains evidence for at least two episodes of colder and drier conditions during this period (mid-14 ${ }^{\text {th }}$ century to mid/late $15^{\text {th }}$ century and $\mathrm{mid} /$ late $16^{\text {th }}$ century to early $20^{\text {th }}$ century), with somewhat milder-warmer conditions in between. The second cool interval is presumed to correspond with the coldest 
phase of the LIA in this region. At the turn of the $20^{\text {th }}$ century, major shifts observed in all proxies were interpreted as reflecting the impact of recent climate warming in this region. At the same time, we noticed a shift towards more clearly defined sediment laminations, decreasing particle size, as well as important changes in diatom community composition.

Down-core variations of $\mathrm{Ti}$ in the sediments were compared with independent reconstructions of regional summer temperatures derived from ice core and varved lake sediment records from Baffin Island. These comparisons revealed significant positive correlations, thereby emphasizing the usefulness of combining geochemical and biostratigraphic proxies in palaeolimnological studies. Further research on the Nettilling Lake sediment archive promises to yield more detailed insights into the climatic and environmental history of this poorly known region of the Canadian Arctic.

\section{Acknowledgements}

This study was made possible through grants from the Natural Sciences and Engineering Research Council (NSERC) of Canada to R. Pienitz and from the Network of Centres of Excellence $\underline{\text { ArcticNet}}$. The Polar Continental Shelf Program 
(PCSP), the Northern Studies Training Program (NSTP) and Centre d'Études Nordiques (CEN) provided logistic support for the fieldwork at Nettilling Lake. Implementation of the IAAFT algorithm for estimating age model errors was facilitated by using MATLAB codes developed and made available by A. Leontitsis and V. Venema.We would like to thank GH Miller and an anonymous reviewer for their insightful comments on an earlier version of the manuscript. 


\section{References}

Antoniades D, Hamilton PB, Douglas MSV, Smol JP (2008) Diatoms of North America: The freshwater floras of Prince Patrick, Ellef Ringes, and Northern Ellesmere Islands from the Canadian Arctic Archipelago. In Lange-Bertalot, H. (ed), Iconographia Diatomologica vol.17, A.R.G. Gantner Verlag K.G.: 649 p.

Antoniades D, Francus P, Pienitz R, St-Onge G, Vincent WF (2011) Holocene dynamics of the Arctic's largest ice shelf. Proceedings of the National Academy of Sciences of the United States of America 108 (47): 18899-18904. DOI: 10.1073/pnas.1106378108.

Appleby P (2001) Chronostratigraphic techniques in recent sediments. In: Last WM and Smol JP (eds) Tracking Environmental Change Using Lake Sediments: Basin Analysis, Coring and Chronological Techniques. Development in Palaeoenvironmental Research (DPER). Springer, pp.171-203.

Axford Y, Briner JP, Cooke CA, Francis DR, Michelutti N, Miller GH, Smol JP, Thomas EK, Wilson CR, Wolfe AP (2009) Recent changes in a remote Arctic lake are unique within the past 200,000 years. Proceedings of the National Academy of Sciences 106 (44): 18443-18446.

Barletta F, St-Onge G, Channell JET, Rochon A (2010a) Dating of Holocene western Canadian Arctic sediments by matching palaeomagnetic secular variation to a geomagnetic field model. Quaternary Science Reviews 29: 2315-2324.

Barletta F, St-Onge G, Stoner SJ, Lajeunesse P, Locat J (2010b) A high-resolution Holocene palaeomagnetic secular variation and relative palaeointensity stack from Eastern Canada. Earth and Planetary Science Letters 298: 162-174.

Battarbee R, Jones V, Flower R, Cameron N, Bennion H, Carvalho L, Juggins S (2002) Diatoms. In: Smol J, Birks J, Last W, Bradley R, Alverson K (eds) Tracking Environmental Change Using Lake Sediments: Terrestrial, Algal, and Siliceous Indicators. Development in Palaeoenvironmental Research (DPER). Springer, pp.155-202.

Birks HJB (2012) Analysis of stratigraphical data. In: Birks HJB, Lotter AF, Juggings S, Smol JP (eds) Tracking Environmental Change Using Lake Sediments: Data handling and numerical techniques. Development in Palaeoenvironmental Research (DPER). Springer, pp.355-378.

Blackadar RG (1967) Geological reconnaissance, southern Baffin Island, District of Franklin. Geological Survey of Canada Paper 66 (47): 32 p. 
Blake Jr W (1966) End moraines and deglaciation chronology in northern Canada with special reference to southern Baffin Island. Geological Survey of Canada Paper 66 (26): $31 \mathrm{p}$.

Blaauw M and Christen JA (2011) Flexible paleoclimate age-depth models using an autoregressive gamma process. Bayesian Analysis 6: 457-474.

Blott S and Pye K (2001) GRADISTAT: A grain size distribution and statistics package for the analysis of unconsolidated sediments. Earth, Surface, Processes and Landforms 26 (11): 1237-1228.

Briner JP, Davis TP, Miller GH (2009) Latest Pleistocene and Holocene glaciation of Baffin Island, Arctic Canada: Key patterns and chronologies. Quaternary Science Reviews 28: 2075-2087.

Cook TL, Bradley RS, Stoner JS, Francus P (2009) Five thousand years of sediment transfer in a high arctic watershed recorded in annually laminated sediments from Lower Murray Lake, Ellesmere Island, Nunavut, Canada. Journal of Paleolimnology 41:77-94.

Croudace IW, Rindby A, Rothwell RG (2006) ITRAX: description and evaluation of a new sediment core scanner. In: Rothwell RG (ed) New ways of looking at sediment cores and core data. Geological Society of London special Publication, pp.51-63.

Cuven S, Francus P, Lamoureux S (2010) Estimation of grain size variability with micro X-ray fluorescence in laminated lacustrine sediments, Cape Bounty, Canadian High Arctic. Journal of Palaeolimnology 44: 803-817.

Dyke (1979) Glacial and Sea-Level History of Southwestern Cumberland Peninsula, Baffin Island, N.W.T.,Canada. Arctic, Antarctic and Alpine research 11(2): 179-202.

Ebisuzaki W (1997) A method to estimate the statistical significance of a correlation when the data are serially correlated. Journal of Climate 10: 2147-2153.

Everett JT and Fitzharris BB (1998) The Arctic and the Antarctic. The regional impacts of climate change. An assessment of vulnerability. A special report of IPCC working group II for the Intergovernmental Panel of Climate Change. Cambridge University Press : 85-103.

Fallu M A, Allaire N, Pienitz R (2000) Freshwater Diatoms from Northern Québec and Labrador (Canada): Species-Environment Relationships in Lakes of Boreal Forest, Forest-Tundra and Tundra Regions. Cramer, Berlin, 200 p.

Fisher DA, Koerner RM, Bourgeois J, Zielinski G, Wake C, Hammer C, Clausen HB, Gundestrup N, Johnsen S, Goto-Azuma K, Hondoh T, Blake E, Gerasimoff M (1998) 
Penny Ice Cap cores, Baffin Island, Canada, and the Wisconsinan Foxe Dome connection: Two states of Hudson Bay ice cover. Science 279: 692-695.

Fisher D, Zheng J, Burges D, Zdanowicz C, Kinnard C, Sharp M, Bourgeois J (2011) Recent melt rates of Canadian Arctic ice caps are the highest in four millennia. Global and Planetary Change 84-85: 3-7. DOI:10.1016/j.glopacha.2011.06.005.

Flower R J (1993) Diatom preservation: experiments and observations on dissolution and breakage in modern and fossil material. Hydrobiologia 269 (270): 473-484.

Grumet NS, Wake CP, Mayewski PA, Zielinski GA, Whitlow SI, Koerner RM, Fisher DA, Woollett JM (2001) Variability of sea ice in Baffin Bay over the last millennium. Climatic Change 49: 129-145.

Heiri O, Lotter A, Lemcke G (2001) Loss on ignition as a method for estimating organic and carbonate content in sediments: reproducibility and comparability of results. Journal of Palaeolimnology 25: 101-110.

Hodgson DA and Smol JP (2008) High-latitude palaeolimnology. In: Vincent WF and Laybourn-Parry J (eds) Polar lakes and rivers: Limnology of Arctic and Antarctic Aquatic Ecosystems. Oxford University Press, pp.43-64.

Hughen K, Overpeck J, Anderson R (2000) Recent warming in the 500-year palaeotemperature record from varved sediments, Upper Soper Lake, Baffin Island, Canada. The Holocene 10: 9-19.

Jackson A, Jonkers ART, Walker MR (2000) Four centuries of geomagnetic secular variation from historical records. Philosophical Transaction of Royal Society of London 358: 957-990.

Jacobs JD and Grondin LD (1988) The Influence of an Arctic Large-Lakes System on Mesoclimate in South-Central Baffin Island, NWY, Canada. Arctic and Alpine Research 20 (2): 212-219.

Jacobs JD, Headley AN, Wang H (1993) Climate Autostation Operations at Remote Integrated Studies Sites in Baffin Island, NWT 1987 - 1992. Canadian Climate Centre Report No. 93-4. Atmospheric Environment Service, Downsview, Ontario, 44 pp.

Jacobs JD, Headley AN, Maus LA, Mode WN, Simms ÉL (1997) Climate and Vegetation of the Interior Lowlands of Southern Baffin Island: Long-term Stability at the Low Arctic Limit. Arctic 50(2): 167-177.

Kaufman DS, Schneider DP, McKay NP, Ammann CP, Bradley RS, Briffa KR, Miller GH, Otto-Bliesner BL, Overpeck JT, Vinther BM and 21 other (2009). Recent warming reverses long-term Arctic cooling. Science 325: 1236-1239. 
Koerner R M (1977) Devon Island ice cap: Core stratigraphy and palaeoclimate, Science 196: 15-18. DOI:10.1126/science.196.4285.15.

Korte $\mathrm{M}$ and Constable C (2011) Improving geomagnetic field reconstructions for 0-3 ka. Physics of the Earth and Planetary Interiors 188: 247-259.

Krammer K and Lange-Bertalot H (1986) Bacillariophyceae 1. Teil: Naviculaceae. In: Ettl H, Gerloff J, Heynig H, Mollenhauer D (eds) Süßwasserflora von Mitteleuropa, Band 2/1. Gustav Fischer Verlag, Stuttgart, 876 pp.

Krammer K and Lange-Bertalot H (1991a) Bacillariophyceae 3. Teil: Centrales, Fragilariaceae, Eunotiaceae. In: Ettl H, Gerloff J, Heynig H, Mollenhauer D (eds) Süßwasserflora von Mitteleuropa, Band 2/3, Gustav Fischer Verlag, Stuttgart, 576 pp.

Krammer K and Lange-Bertalot H (1991b) Bacillariophyceae 4. Teil: Achnanthaceae, Kritische Ergänzungen zu Navicula (Lineolatae) und Gomphonema Gesamtliteraturverzeichnis Teil 1-4. In: Ettl H, Gerloff J, Heynig H, Mollenhauer D (eds) Süßwasserflora von Mitteleuropa, Band 2/4. Gustav Fischer Verlag, Stuttgart, $436 \mathrm{pp}$.

Lamoureux SF (1994) Embedding unfrozen lake sediments for thin section preparation. Journal of Palaeolimnology 10(2):141-146.

Lamoureux S and Gilbert R (2004) A 750-yr record of autumn snowfall and temperature variability and winter storminess recorded in the varved sediments of Bear Lake, Devon Island, Arctic Canada. Quaternary Research 61: 134-147.

Lewis T, Gilbert R, Lamoureux SF (2002) Spatial and Temporal Changes in Sedimentary Processes at Proglacial Bear Lake, Devon Island, Nunavut, Canada. Arctic, Antarctic and Alpine Research 34(2): 119-129.

Margreth A, Dyke AS, Gosse JC, Telka AM (2014) Neoglacial ice expansion and late Holocene cold-based ice cap dynamics on Cumberland, Peninsula, Baffin Island, Arctic Canada. Quaternary Science Reviews 91: 242-256.

Mazaud A (2005) User-friendly software for vector analysis of the magnetization of long sediment cores. Geochemistry, Geophysics, Geosystems 6(12): 1-5.

Miller GH, Geirsdóttir A, Zhong Y, Larsen DJ, Otto-Bliesner BL, Holland MM, Bailey DA, Refsnider KA, Lehman SJ, Southon JR, Anderson C, Björnsson H, Thordarson T (2012) Abrupt onset of the Little Ice Age triggered by volcanism and sustained by seaice/ocean feedbacks. Geophysical Research Letters 39: L02708 doi:10.1029/

2011 GL050168. 
Miller GH, Lehman SJ, Refsnider KA, Southon JR, Zhong Y (2013) Unprecedented recent summer warmth in Arctic Canada. Geophysical Research Letters 40: 57455751.

Moore JJ, Hughen KA, Miller GH, Overpeck JT (2001) Little ice age recorded in summer temperature reconstruction from varved sediments of Donard Lake, Baffin Island, Canada. Journal of Palaeolimnology 25: 503-517.

Moore GWK (2006) Reduction in seasonal sea ice concentration surrounding southern Baffin Island 1979-2004. Geophysical Research Letters 3(20): 1-5.

Narancic B, Chapligin B, Meyer H, Francus P, Pienitz R (2013) Postglacial environmental succession of Nettilling Lake (Baffin Island, Canadian Arctic) inferred by biogeochemical and microfossil proxies. In: European Geosciences Union General Assembly 2013, Vienne, Austria, 7-12 April 2013.

Oliver DR (1964) A limnologic investigation of a large Arctic lake, Nettilling Lake, Baffin Island. Arctic 17 (2): 69-83.

Overpeck J, Hughen K, Hardy D, Bradley R, Case R, Douglas M, Finney B, Gajewski K, Jacoby G, Jennings A, Lamoureux S, Lasca A, MacDonald G, Moore J, Retelle M, Smith S, Wolfe A, Zielinski G (1997) Arctic environmental change of the last four centuries. Science 278: 1251-1256.

Paillard (2006) AnalySerie Software. Available at :

http://www.lsce.ipsl.fr/Phocea/Page/index.php?id=3 (accessed on 22 September 2014).

Pienitz R (2001) Techniques de Reconstitution du Développement des Tourbières: Analyse des Diatomées. In: Payette S and Rochefort L (eds) Écologie des Tourbières du Québec-Labrador. Presses de l'Université Laval, Québec, . 311-326 pp.

Pienitz R, Douglas MSV, Smol JP (2004) Palaeolimnological research in polar regions : An introduction. In: Pienitz R, Douglas MSV, Smol JP (eds) Long-Term Environmental Change in Arctic and Antarctic Lakes. Development in Palaeoenvironmental Research (DPER). Springer, pp.1-12.

Rolland N, Larocque I, Francus P, Pienitz R, Laperrière L (2009) Evidence for a warm period during the 12th and 13th centuries $\mathrm{AD}$ from chironomid assemblages in Southampton Island, Nunavut, Canada. Quaternary Research 72: 27-37.

Rothwell G and Rack F (2006) New techniques in sediment core analysis: an introduction. In: Rothwell G (ed) New techniques in sediment core analysis. Geological Society, London Special Publications 267: 1-29. 
Ryves DB, Battarbee RW, Fritz SC (2009) The dilemma of disappearing Diatoms: Incorporating diatom dissolution data into palaeoenvironmental modeling and reconstruction. Earth and Atmospheric Science 128: 120-136.

Schreiber T and Schmitz A (1996) Improved surrogate data for nonlinearity tests. Physical Review Letters 77: 635-638.

Stoner JS and St-Onge G (2007) Magnetic stratigraphy in palaeoceanography: reversals, excursions, palaeointensity and secular variation. In: Hillaire-Marcel C and De Vernal A (eds) Proxies in Late Cenozoic Palaeoceanography. Elsevier, pp.99-137.

St-Onge G and Stoner JS (2011) Paleomagnetism near the North Magnetic Pole: a unique vantage point to understand the dynamics of the geomagnetic field and its secular variations. Oceanography 24: 42-50.

St-Onge M.R, Wodicka N and Ijewliw O (2007) Polymetamorphic evolution of the Trans-Hudson Orogen, Baffin Island, Canada: Integration of petrological, structural and geochronological data. Journal of Petrology 48: 271- 302. doi:10.1093/petrology/eg1060.

Tauxe L (2010) Essentials of palaeomagnetism. University of California Press, Berkeley, California, USA, 489 pp.

Thomas EK and Briner JP (2009) Climate of the past millennium inferred from varved proglacial lake sediments on northeast Baffin Island, Arctic Canada. Journal of Paleolimnology 49: 209-224.

Vologina EG, Granin NG, Vorobeva SS, Francus P, Lomonosova TK, Kalashnikova IA \& Granina LZ (2005) Ice-rafting of sand-silty material in South Baikal. Russian Geology and Geophysics 46 (4): 420-427 (in Russian).

Wolfe A and Smith R (2004) Palaeolimnology of the middle and high Canadian Arctic. In: Pienitz R, Douglas MSV, Smol JP (eds) Long-Term Environmental Change in Arctic and Antarctic Lakes. Development in Palaeoenvironmental Research (DPER). Springer, 8(9): 241-268.

Zdanowicz C, Smetny-Sowa A, Fisher D, Shaffer N, Copland L, Eley J, Dupont F (2012) Summer melt rates on Penny Ice Cap, Baffin Island: Past and recent trends and implications for regional climate. Journal of Geophysical Research, 117 (F02006): 21 pp. 


\section{Supplementary files: : ${ }^{210} \mathrm{~Pb}$ and ${ }^{14} \mathrm{C}$ data}

In addition to ${ }^{137} \mathrm{Cs}$, radiocarbon $\left({ }^{14} \mathrm{C}\right)$ and lead $210\left({ }^{210} \mathrm{~Pb}\right)$ analyses were also performed on core Ni5-8, but results of these analyses (presented below; Figure 1A) were not used for the age model development. The ${ }^{210} \mathrm{~Pb}$ data were rejected on the grounds that sediment-bound $\mathrm{Pb}$ entering the lake with glacial silt likely masks or at least distorts the atmospheric ${ }^{210} \mathrm{~Pb}$ signature.

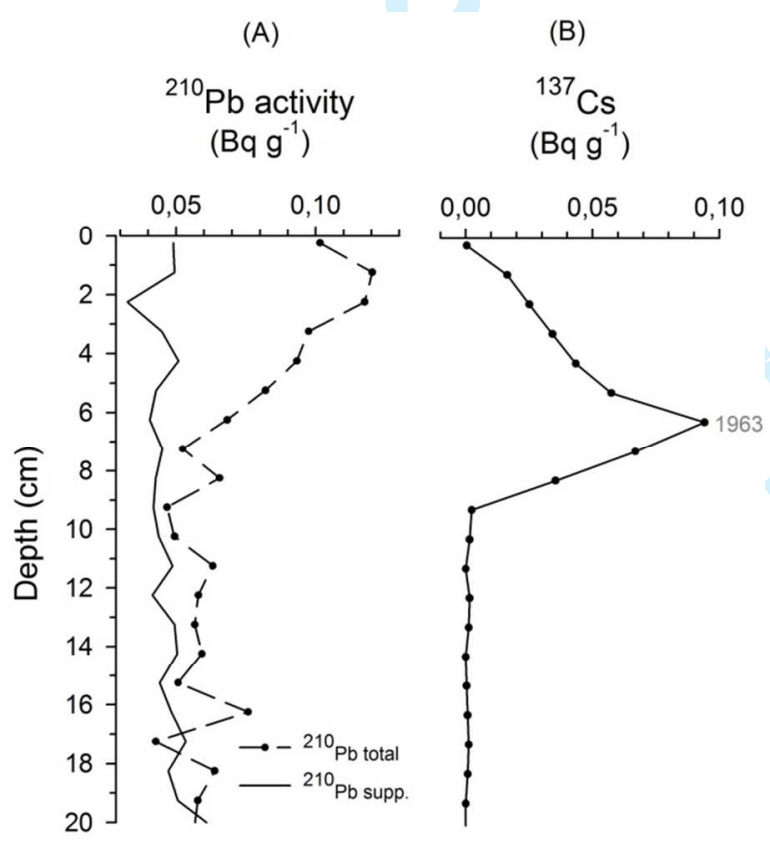

Figure 1. Chronology of the uppermost sediments $\left({ }^{210} \mathrm{~Pb}\right.$ and $\left.{ }^{137} \mathrm{Cs}\right)$ for core Ni5-8. (A) Total (measured) and supported ${ }^{210} \mathrm{~Pb}$ activity (the difference gives the ${ }^{210} \mathrm{~Pb}$ in excess used to calculate the sedimentation flux). (B) ${ }^{137} \mathrm{Cs}$ activity (Appleby, 2001).

Attempts to date the bottom of the core were made with radiocarbon ages determined by Accelerator Mass Spectrometry (AMS) on 6 samples of bulk sediment at the Keck Carbon Cycle Accelerator Mass Spectrometry Laboratory (University of California, 
Irvine). The ${ }^{14} \mathrm{C}$ conventional ages were converted to calibrated ages with the CALIB 6.0.1 software (Stuiver and Reimer, 1993).

The 6 radiocarbon dates obtained from core Ni5-8 ranged from 1805 to $11,235{ }^{14} \mathrm{C} \mathrm{BP}$ (Table 1), but 2 out of these 6 dates did not conform to the expected increasing depth-age relationship. Furthermore, in view of the known post-glacial retreat and emergence history of the Nettilling Lake region, some of the ${ }^{14} \mathrm{C}$ dates are too old. No marine sediments (e.g., shells) were found in the core, as might be expected if the deeper layers pre-dated postglacial emergence (prior to $\sim 6.7 \mathrm{ka} \mathrm{BP}$ ), thus making it unlikely that core Ni5-8 spans the full time range suggested by the ${ }^{14} \mathrm{C}$ dates (Blake, 1966; Dyke, 1979; Jacobs et al., 1997).

Table 1. Radiocarbon $\left({ }^{14} \mathrm{C}\right)$ and calibrated (cal a BP) ages from core Ni5-8.

\begin{tabular}{ccccc}
\hline Depth $(\mathbf{c m})$ & Lab & Material & Age $\left(^{14} \mathbf{C}\right.$ a BP) & Midpoint (cal a BP) \\
\hline $5.5-6$ & ULA-3541 & bulk sediment & $8090 \pm 35$ & 9053 \\
$15.5-16$ & ULA-3542 & bulk sediment & $1805 \pm 15$ & 1758 \\
$31.5-32$ & ULA-1889 & bulk sediment & $2230 \pm 20$ & 2216 \\
$47.5-48$ & ULA-1890 & bulk sediment & $4105 \pm 20$ & 4587 \\
$65.5-66$ & ULA-1891 & bulk sediment & $11235 \pm 35$ & 13172.5 \\
$82.5-83$ & ULA-1892 & bulk sediment & $9695 \pm 30$ & 11146.5 \\
\hline
\end{tabular}

A plausible explanation for these anomalous ${ }^{14} \mathrm{C}$ ages is contamination by old (low ${ }^{14} \mathrm{C}$ activity) carbon from the watershed, which may contain organic carbon of different age and composition than that produced in the lake itself (Nelson, 1988; Abbott, 1996).

\section{References}

Abbott MB and Stafford TW (1996) Radiocarbon geochemistry of modern and ancient Arctic lake systems, Baffin Island, Canada. Quaternary Research 45: 300-311.

Appleby P (2001) Chronostratigraphic techniques in recent sediments. In: Last WM and Smol JP (eds) Tracking Environmental Change Using Lake Sediments: Basin Analysis, Coring and Chronological Techniques. Development in Palaeoenvironmental Research (DPER). Springer, pp.171-203. 
Blake Jr W (1966) End moraines and deglaciation chronology in northern Canada with special reference to southern Baffin Island. Geological Survey of Canada Paper 66 (26): $31 \mathrm{p}$.

Dyke (1979) Glacial and Sea-Level History of Southwestern Cumberland Peninsula, Baffin Island, N.W.T.,Canada. Arctic, Antarctic and Alpine research 11(2): 179-202.

Jacobs JD, Headley AN, Maus LA, Mode WN, Simms ÉL (1997) Climate and Vegetation of the Interior Lowlands of Southern Baffin Island: Long-term Stability at the Low Arctic Limit. Arctic 50(2): 167-177.

Nelson RE, Carter LD, Robinson SW (1988) Anomalous radiocarbon ages from a Holocene detrital organic lens in Alaska and their implications for radiocarbon dating and palaeoenvironmental reconstructions in the Arctic. Quaternary Research 29: 6671.

Stuiver M and Reimer P (1993) Extended ${ }^{14} \mathrm{C}$ database and revised CALIB radiocarbon calibration program. Radiocarbon 35: 215-230. 


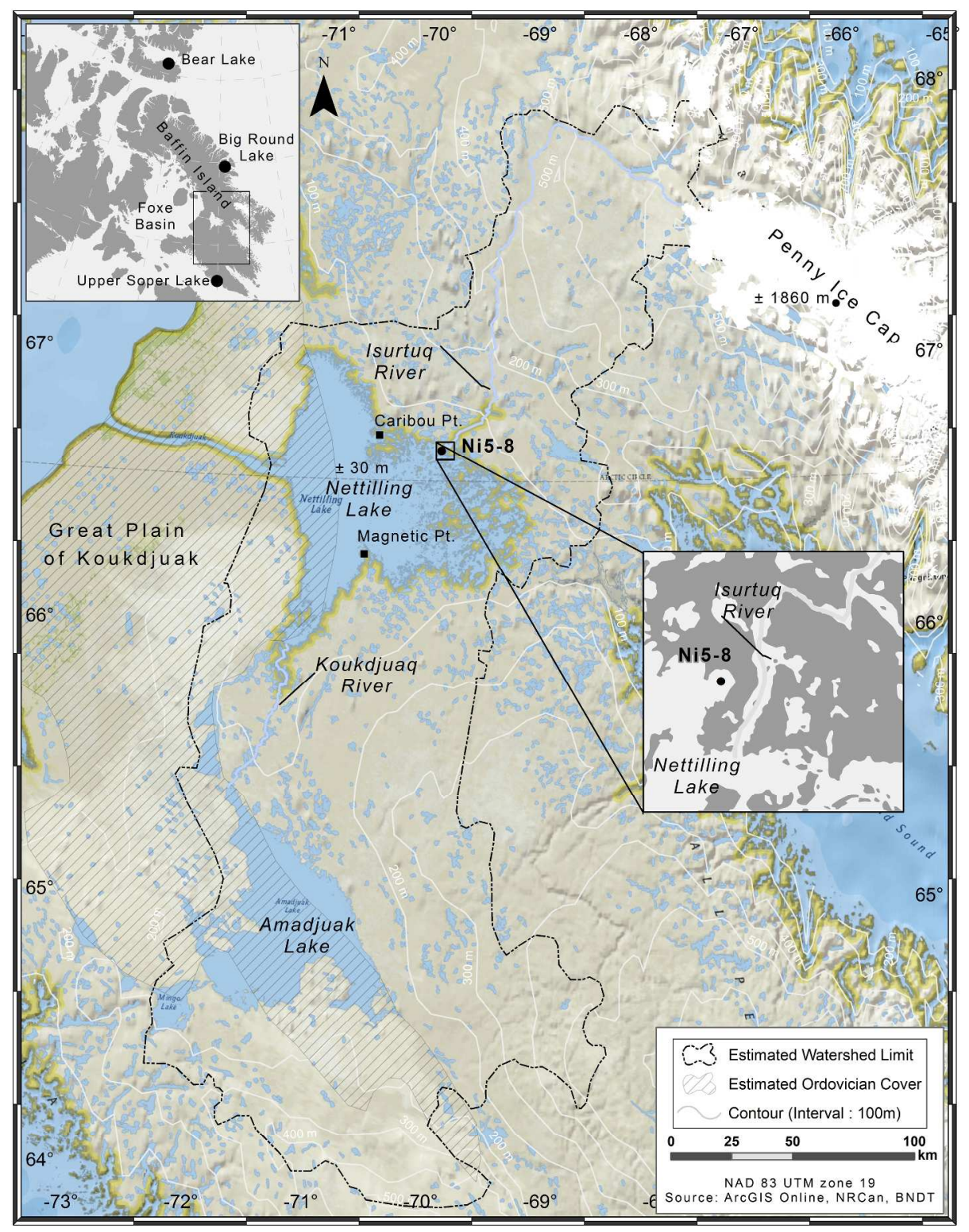

Figure 1. Location map with Nettilling Lake, Penny Ice Cap and surrounding region. Ni5-8 = lake coring site in 2010. Nettilling lake watershed limit modified from Jacob et al, 1997. Ordovician cover extent modified from St-Onge et al, 2007. $279 \times 361 \mathrm{~mm}(300 \times 300 \mathrm{DPI})$ 

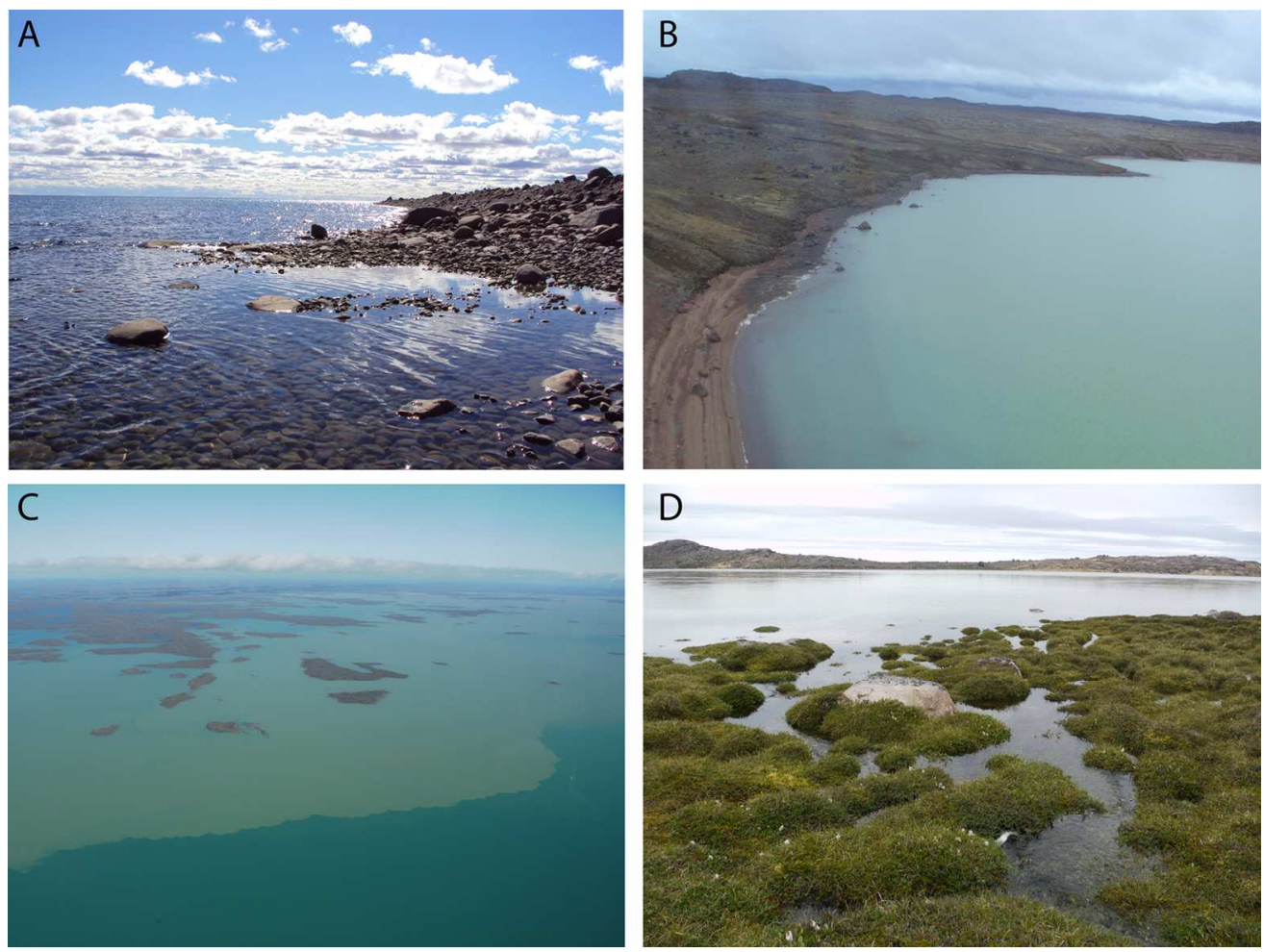

Figure 2. A) Transparent waters of the western part of Nettilling Lake; B) Inputs of glacial meltwater highly charged with silt in the eastern part of the lake (Photos: Anne Beaudoin, August 2010); C) Plume of sediments in Nettilling Lake from glacial meltwater highly charged with silt; D) Moss- and sedge-dominated wetlands along the banks of the Isurtuq River, near its inflow into Nettilling Lake (Photos: Reinhard Pienitz, August 2014).

$128 \times 96 \mathrm{~mm}(300 \times 300 \mathrm{DPI})$ 
Figure 3. Comparison of (A and B) palaeomagnetic inclination records from the Nettilling Lake core Ni5-8; dashed line $={ }^{137} \mathrm{Cs}$ activity, (C) output from the CALS3k.4 model for this region (Korte and Constable, 2011), (D) output of the GUMF1 model (Jackson et al., 2000), and (E) the Eastern Canadian Stack (Barletta et al., 2010b). $121 \times 68 \mathrm{~mm}(300 \times 300 \mathrm{DPI})$ 


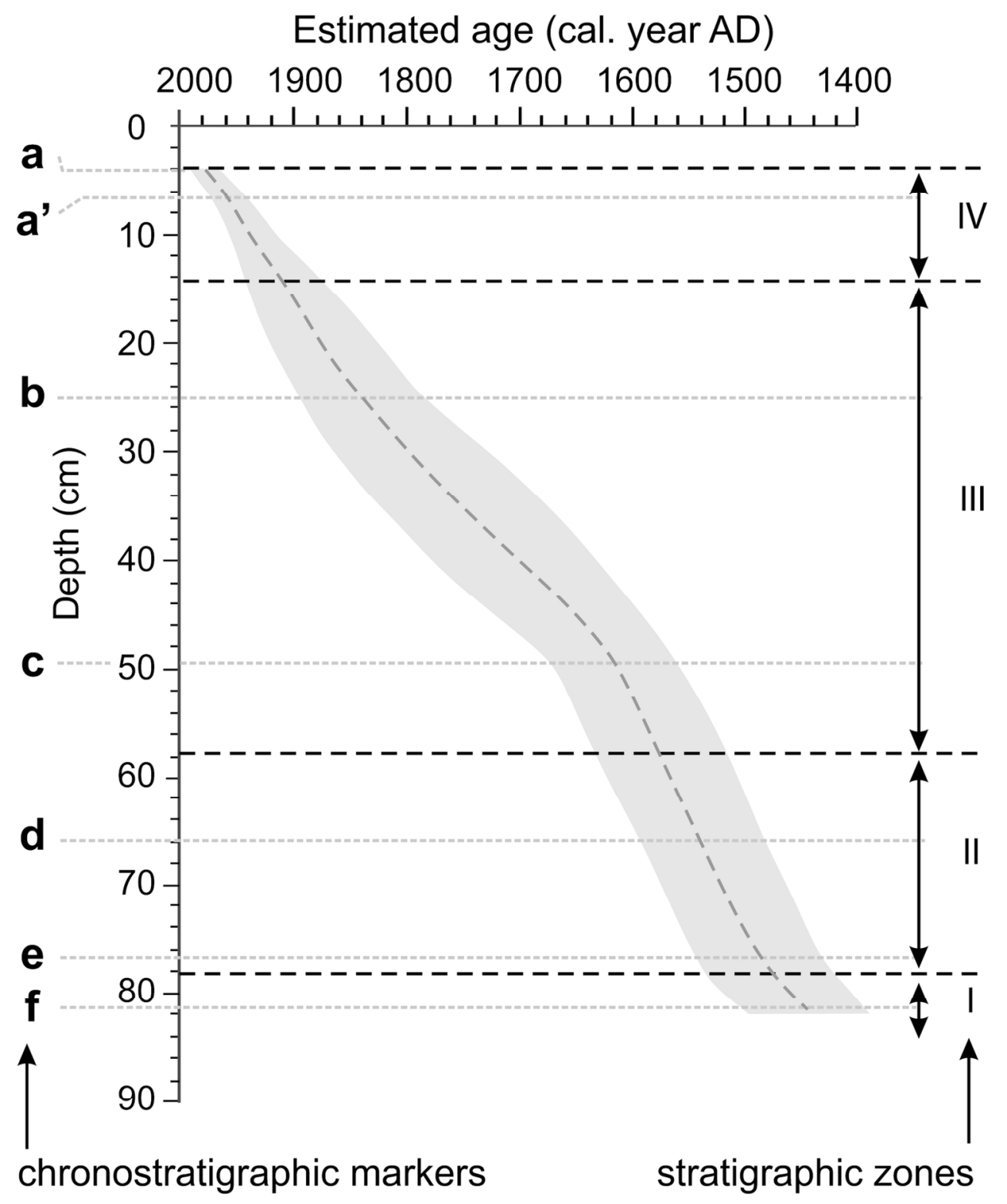

Figure 4. Age-depth model for core Ni5-8, constructed using chronostratigraphic markers identified using ${ }^{137} \mathrm{Cs}$ and the palaeomagnetic inclination curve (Table 1 ). The broken line is the median age estimate and the gray shading the corresponding $95 \%$ confidence bounds, as determined using a Markov chain Monte Carlo procedure. Letters at left identify chronostratigraphic markers (Table $1: a^{\prime}=1963{ }^{137} \mathrm{Cs}$ bomb layer). Numbers at right denote stratigraphic zones (I to IV) defined by distinctive sedimentological and geochemical variations (see text). $134 \times 163 \mathrm{~mm}(300 \times 300 \mathrm{DPI})$ 


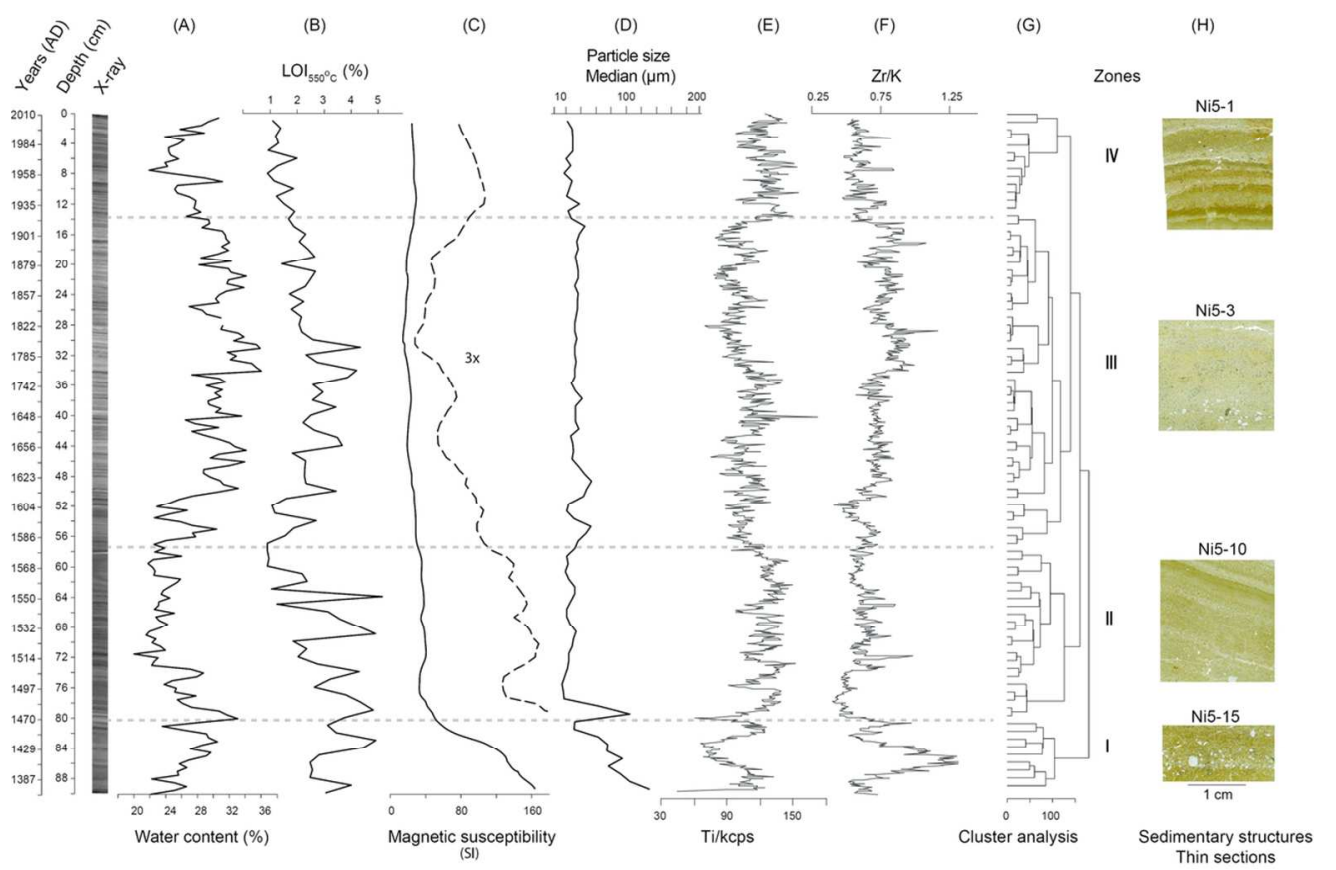

Figure 5. Summary diagram of Nettilling Lake core showing lithostratigraphic characteristics. (A) Water content in percentage; (B) Organic matter in percentage; (C) Magnetic susceptibility of the core with 3-fold exaggeration of the abscissa to emphasize the details; (D) Particle size analysis (median $\mu \mathrm{m}$ ); (E) Ti/kcps : $\mu$-XRF results from Nettilling lake sedimentary sequence. Elemental profile in peak areas is normalized by total counts per second (kcps) at the corresponding depth. Sinalo elemental and ratio profiles are presented with 10-point averages. Ti profile is terrigenous indicators (2) $\mathrm{Fr} / \mathrm{K}$ ratio is a proxy for particle-size estimation; (G) Cluster analysis revealing four stratigraphic zones; $(H)$ Typical sedimentary structures observed in thin sections. $107 \times 70 \mathrm{~mm}(300 \times 300$ DPI) 


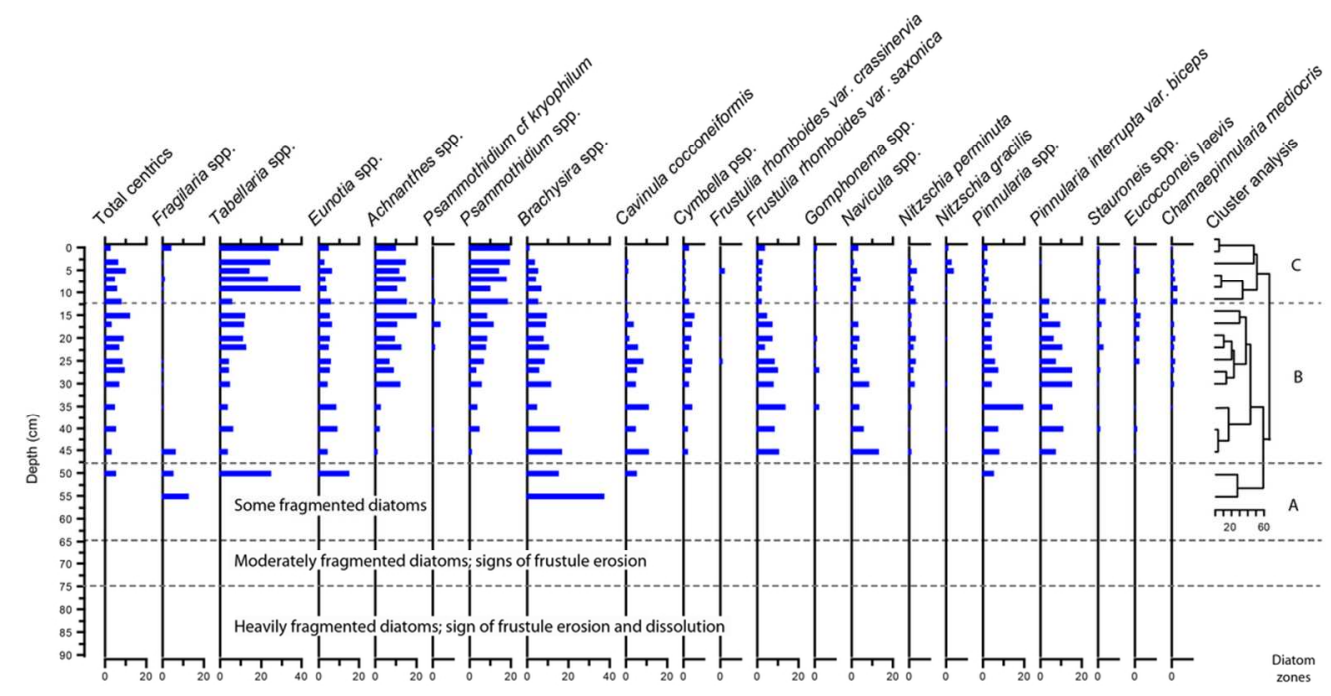

Figure 6. Summary biostratigraphy of diatom taxa in core Ni5-8 expressed as relative abundances (\%). Only taxa with $>2 \%$ abundance in at least one level are shown.

$96 \times 50 \mathrm{~mm}(300 \times 300 \mathrm{DPI})$ 


\section{Page 55 of 54}

(D)

(E)
(C)
Upper Soper Lake Varve thickness $(\mathrm{mm})$

$\begin{array}{llllll}0 & 20 & 40 & 60 & 80 & 100120\end{array}$ $\begin{array}{lllllll}0 & 0.2 & 0.4 & 0.6 & 0.81 .0 & 1.2\end{array}$

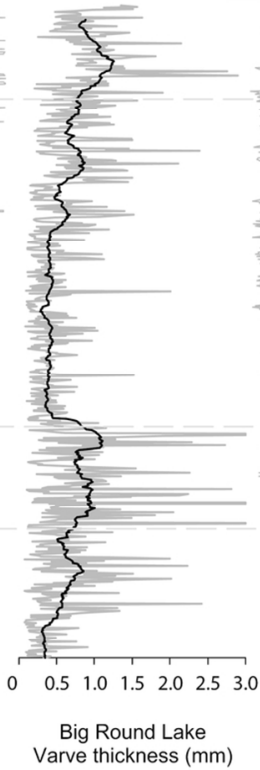

IV

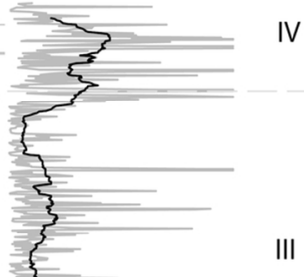

\section{I}

7. Comparison of the (A) titanium profile from the Nettilling Lake sediment record (30 yr running mean) with (B) melt features from the Penny Ice Cap (Fisher et al., 1998), (C) varve thickness from Big Round Lake (Thomas and Briner, 2009), (D) varve thickness from Upper Soper Lake (Hughen et al., 2003) and (E) varve thickness from Bear Lake (Lamoureaux and Gilbert (2004). Black lines are 30-yr running means.

$110 \times 78 \mathrm{~mm}(300 \times 300$ DPI $)$ 